\title{
COMMUNICATION PATTERNS OF SOCIAL ASSISTANT PROGRAM FOR THE HARAPAN FAMILY IN THE ACTIVITIES OF FAMILY CAPABILITY IMPROVEMENT MEETINGS (P2K2) BENEFICIARY FAMILY (KPM) BALIGE DISTRICT
}

\author{
Rammen Andino Sinaga \\ PKH Social Assistance, Toba Regency PKH \\ andinosinaga@gmail.com
}

\begin{abstract}
This study aims to look at the communication patterns of the social companions of the Family Hope Program in the Family Capacity Building Meeting (P2K2) in Balige District. Family Capacity Building (P2K2) carried out by Social Assistance to beneficiary families (KPM) basically has the same goal as the Sustainable Development Goals (SDGs) which is to improve the welfare and safety of the community in order to improve the ability of the underprivileged to manage their daily lives. . With the following conclusions: (1) Family Capacity Building Activities have interaction between social assistants and families who are beneficiaries of the social assistance. This interaction creates an emotional closeness between the parties involved. In this activity, communication between the parties involved. The effective communication starts from the closeness and shared experience between the Social Facilitator and the beneficiary. With the results of the study as follows, the communication used in Family Capacity Building activities is a type of interpersonal communication and group communication. (2) In P2K2 activities, social assistants must take an emotional approach to KPM PKH because emotional closeness will increase the extrinsic motivation of KPM PKH. (3) Communication barriers in P2K2 activities, social assistants must take more persuasive and humane actions, so that the message conveyed can be well received. (4) P2K2 Balige District can be said to be effective communication, because the purpose.
\end{abstract}

Keyword : P2K2, Effective Communication and Communication Barriers

\section{A. INTRODUCTION}

Communication is the most important thing in the delivery of information, in communication activities the giver and recipient of information must understand and implement or provide feedback on the information that has been obtained. Effective communication can occur when each party, both the recipient and the giver of information, can overcome communication barriers, each obstacle can be used as a new communication medium. Every human being, requires communication as the right pattern to solve problems in every activity. Communication must be owned by each individual in order to describe an independent human being and have the freedom to express opinions, as an independent human being.

The Family Hope Program is one of the programs from the Ministry of Social Affairs to improve consumption patterns, living standards of the underprivileged, which in its activities the Ministry of Social Affairs assigns social assistants who have the functions of advocacy, guidance and teaching. The guidance carried out in the Family Hope Program is a Family Capacity Building (P2K2) activity carried out by Social Facilitators whose subjects of empowerment and mentoring are residents who are beneficiaries of receiving the Social Assistance Program for the Family Hope Program (PKH). The Family Capacity Building (P2K2) activity has learning modules which are divided into five (5) major modules, namely the Nutrition Health Module, Parenting and Education Module, Child Protection Module, Financial Management Module and Social Welfare Module. 
After receiving education and training from the Ministry of Social Affairs, every social assistant for the Family Hope Program must take the certification of Social Welfare Personnel for social assistants whose educational background is not social welfare and certification of social workers whose educational background is social welfare. The Family Capacity Building Activities (P2K2) carried out by Social Assistance to beneficiary families (KPM) basically have the same goals as the Sustainable Development Goals (SDGs) which are to improve the welfare and safety of the community in order to improve the ability of the underprivileged to manage their daily lives. day. Family Capacity Building Activities have interactions between social assistants and the beneficiary families of the social assistance. This interaction creates an emotional closeness between the parties involved. In this activity, communication occurs between the parties concerned. The effective communication starts from the mutual closeness and shared experience between the Social Facilitator and the beneficiary.

However, in practice, there are many barriers to communication between social assistants and beneficiary families. Social assistance recipients have different educational backgrounds and different ages. But the implementation is done simultaneously. The most obvious obstacle is that there are still recipients of social assistance who are still illiterate and unable to use Indonesian well, in the context of this study the beneficiaries often use the Batak Toba language. Simultaneous implementation of the modules sometimes becomes an obstacle, for example when the health and nutrition module is implemented, the elderly beneficiaries are less enthusiastic, and vice versa is when the social welfare module, elderly beneficiaries are enthusiastic and young mothers are less enthusiastic. enthusiastic.

Another obstacle is that these activities have modules that are very close to the lives of the beneficiary communities, so that sometimes the beneficiaries feel bored and bored in the capacity building activities of the family. Social Facilitators must be present not to be teachers for them, but to be assistants who provide assistance. The Beneficiary Family (KPM) must be a source of learning for their social assistants, because after the end of their life experience, they are the parents of the social assistant. This obstacle must be solved by the social assistant, where the social assistant must be present and teach not as if he were teaching but accompanying him in every learning process.

The concept of education carried out is the concept of education. Andragogy is a process to involve adult learners into a structure of learning experience. The concept of education that emphasizes the learning experience, this is where the effective communication side must occur, how social companions turn obstacles into opportunities to improve learning goals. The learning objectives in the Family Capacity Building activity begin with communication between the social assistant and the recipient of the social assistance. Improving Family Capacity must be understood as a learning process through communication. How about a social mentor, making learning not boring so that the transfer of knowledge through communication activities can run well. Social assistants use ice breaking techniques where games are provided, and learning tools that can support the learning process. The use of laptops, speakers and infocus to play videos and films that fit the module is a way to improve communication between social facilitators and social beneficiaries

This Family Capacity Building activity is very important to do, because poverty is spread (multiplier effects), in the order of life. Because poverty is very closely related to the inability to manage and manage cases that occur in their daily lives. How to educate good children so that children are successful in school, how motivation can be given to children from social assistance recipients to continue their education to a higher level. The effects that are diffuse need to be anticipated with the existing pattern of social assistance. With a good and effective communication pattern in the activity of increasing the ability of the family, it must be used as a potential to overcome these problems, both existing obstacles are used as opportunities. Communication can increase the extrinsic motivation of the recipients of the social assistance. Messages that exist and are packaged in family capacity building. 
Communication Patterns Of Social Assistant Program For The Harapan Family In The Activities Of Family Capability Improvement Meetings (P2K2) Beneficiary Family (KPM) Balige District

Rammen Andino Sinaga

It is hoped that in this activity of Capacity Building for Families who receive social assistance, residents who receive social benefits can increase their independence and fighting power. Because of the poverty they have experienced so far, it has made them think skeptical and pessimistic about a bright future for both their families and their children. This expectation can be illustrated by increasing the social and economic strength of the beneficiary residents who are assessed by their social assistants. The ability to communicate and overcome obstacles and as a problem solver must be possessed by the social assistant. These abilities must be honed, and carried out by the social assistant, illustrates that the power of words or communication can change a behavior. Positive behavior will change the habituation of his life

\section{B. UNDERSTANDING OF COMMUNICATION}

Communication or in English communication comes from the Latin word communicatio, and comes from the word communis which means the same. Same here means the same meaning. The same thing was expressed by Hafied Cangara, communication stems from the Latin word communis which means to make togetherness or build togetherness between two or more people. From the above opinion that in the communication process there are different interactions between two more, so in an effective communication process the message under in communication activities that the message bearer and the recipient of the message understand about the goals and objectives to be achieved. According to experts quoted by Danil Vardiasnyah, several definitions of communication in terms put forward by experts:

According to Berelson \& Stainer Communication is a process of delivering information, ideas, emotions, expertise, and others. Through the use of symbols such as words, pictures, numbers, and others. According to Gode, communication is a process that makes something from what was originally owned by a person (one's monopoly) to be owned by two or more people. According to Brandlun, communication arises driven by the needs to reduce a sense of uncertainty, act effectively, maintain or strengthen the ego. From the expert opinion above, we can conclude that in the pattern of communication interaction there is a change that is expected from the recipient and the sender of the message, communication becomes a very common thing to change behavior. In the context of this mini-research, the opinion of Type \& Kelly is very appropriate, because the message is expected to change the behavior of the recipient of the message. Social assistants are communicators and Social Assistance Beneficiary Families are stimulus recipients. Action and reaction is the right conclusion in a communication process.

The reactions that arise in communication activities are able to describe how the response received from the recipient of the message, whether it has an impact on changes in the independence and socio-economic stability of the assisted residents. Communication can be done either through voice messages, numbers and symbols that can be understood well. Because this mini research, relates to the pattern of communication and interaction between humans and humans in the perspective of social assistance recipients and in the intervention of activities that must have the perspective of values and social norms that apply in the midst of society. So that the understanding of communication we must get from Intercultural Communication which was found by Walstrom from various sources mentions several definitions of communication, namely:

1. Human communication is often defined as the most effective self-statement.

2. Communication is the exchange of messages in writing and verbally through conversation, or even through imaginary depictions.

3. Communication is the sharing of information or the provision of entertainment through words orally or in writing by other methods.

4. Communication is the transfer of information from one person to another.

5. The exchange of meaning between individuals using the same symbol system.

6. Communication is the process of transferring messages by one person through a certain channel to another with a certain effect. 


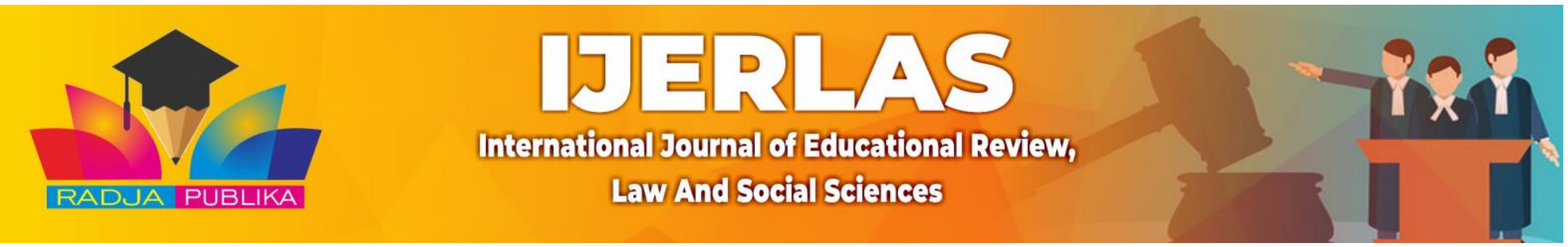

7. Communication is the process of sharing information, ideas or feelings that are not only done verbally and in writing but also through body language, or personal style or appearance

The opinion above suggests that in cultural communication, it can be done through everyday conversation, imaginary symbols and typical methods. We can conclude that the methods that can be used are methods that are in accordance with the local culture. The opinion above also suggests that there is a sharing of information or ideas that can have an effect, so that actions and reactions always exist in communication patterns. Where in general communication is the provision of information both verbally and non-verbally both messages and ideas that are conveyed for the sake of a response in their activities. Susanto stated that there are five communication contexts, namely: intrapersonal communication (intrapersonal communication), interpersonal communication (interpersonal communication), group communication (group communication), organizational communication (organizational communication) and mass communication (mass communication). The author only takes 1 expert in forms of communication, because there are other experts who combine or separate these forms of communication.

Because in the context of the social assistants and the recipients of social assistance, they carry out these five forms of communication, but in this mini research, social assistants often carry out group, interpersonal or even mass communication on a large scale if the family capacity building meeting combines several groups/ villages in one sub-district, but generally only use interpersonal and group communication. Interpersonal communication is a communication process that occurs within a person. This communication generally discusses the process of understanding, remembering and interpreting symbols that are captured through the five senses. More specifically, it can be said that this communication is communication that occurs to oneself, which is done intentionally or unintentionally. Interpersonal communication or interpersonal communication is the process by which people create and manage their relationships, carrying out mutual responsibilities in creating meaning. Furthermore, interpersonal communication is a systematic series of purposeful behaviors that occur from time to time and repeatedly. interpersonal communication is carried out

\section{FAMILY CAPACITY BUILDING MEETINGS AND COMMUNICATION PATTERNS}

Education on KPM in the form of group learning is called the Family Capacity Building Meeting (P2K2). The Family Capacity Building Meeting (P2K2) in other terms called the Family Development Session (FDS) is one form of intervention carried out by the government through the Family Hope Program (PKH) to deal with vulnerable and underprivileged families. The Ministry of Social Affairs (2018:5) said, "The Family Capacity Building Meeting is a structured learning process to accelerate behavior change in Beneficiary Families. P2K2 is carried out face-to-face and facilitated by Social Facilitators who have been established and spread throughout Indonesia, both in urban and rural areas. P2K2 is carried out at least once every month.

There are five learning materials given to KPM in P2K2, namely:

1) Child Care and Education;

2) Financial Management and Business Planning;

3) Health and Nutrition;

4) Child Protection; and

5) Social Welfare: Disability and Elderly.

What is learned in the Parenting and Child Education materials are: being a good parent; understand the development and behavior of children; understand how early childhood learns; and help children succeed in school (Ministry of Social Affairs, 2018:3-4). For the material on Financial Management and Business Planning, the subjects studied are: managing family finances; careful borrowing and saving; and start a business (Ministry of Social Affairs, 2018:3). Health and 
Communication Patterns Of Social Assistant Program For The Harapan Family In The Activities Of Family Capability Improvement Meetings (P2K2) Beneficiary Family (KPM) Balige District

Rammen Andino Sinaga

Nutrition Materials learn about: the importance of nutrition and health services for pregnant women; the importance of nutrition for breastfeeding mothers and toddlers; and morbidity in children and environmental health (Ministry of Social Affairs, 2018:3-4). Child Protection Materials learn about efforts to prevent violence \& mistreatment of children; and neglect \& exploitation of children (Ministry of Social Affairs, 2018:5-6). The last is the material on Social Welfare: Disability and Elderly, discussing services for people with severe disabilities; and the importance of the welfare of the elderly (Ministry of Social Affairs, 2018:3).

The form of communication in P2K2 is group communication. Learning with KPM is carried out in groups and facilitated by Social Facilitators. The purpose of P2K2/FDS is for KPM to experience behavioral changes. This is related to the science of communication. Samovar et.al (2014:17) suggests, one of the functions of communication is to influence the behavior of others. This opinion is the same as the opinion of Devito (2011: 32), that communication aims to change the attitudes and behavior of others. It can be said that P2K2/ FDS is a communication process between Social Facilitators and KPM. Social Facilitators convey information and try to persuade them to do so, with the hope that the quality of life of KPM will improve. P2K2/FDS has a strategic role in achieving poverty reduction targets through $\mathrm{PKH}$.

The development of the poor that is carried out through P2K2/FDS PKH is included in development from a knowledge perspective. Nasution (2009:68) says that development from a knowledge perspective is called "knowledge for development" or "knowledge-based development". Factors that

\section{RESEARCH METHOD}

This research is a qualitative research where research that isdescriptiveand tend to use analysis. Process and meaning (subject perspective) are more highlighted in qualitative research. Basetheoryused as a guide so that the research focus is in accordance with thefactin the field. In addition, this theoretical basis is also useful for providing an overview of the research background and as a material for discussing research results. using in-depth interviews and focus groups. The nature of this type of research is open-ended research and exploration, and ends with a relatively small group of interviewees being interviewed in depth. The research was conducted from December 17, 2020 to December 30, 2020. Where the researcher conducted interviews with the Balige District Social Assistant at the Toba District Social Service office and participated in the implementation of P2K2 in Balige District four times. Observations were carried out in Balige District, Toba Regency, North Sumatra Province. During the period stated above. With the description of Key Informants (Key Infroman)
1. Name
: Abraham Napitupulu, ST
Basic Education Year
Entry Year
$: 2013$
P2K2 Training
$: 2013$
Position
Certification
$: 2018$
2. Name
Basic Education Year : 2018
Entry Year $\quad: 2018$
$\begin{array}{ll}\text { Entry Year } & : 2018 \\ \text { P2K2 Training } & : 2020\end{array}$
Position
Certification
3. Name
Basic Education Year
Entry Year
P2K2 Training
Position
: 2013
: 2013
: 2019
: Social Assistant for Balige District
: Social Welfare Personnel Certification
: Desima Pardede, S.Pd
: Social Assistant for Balige District
: Social Welfare Personnel Certification
: Tambunan July Party, S.Pd
: Coordinator of Social Assistance for Kec. Balige 
Certification

4. Name

Entry Year

Position

5. Name

Entry Year

Position
: Social Welfare Personnel Certification

: Friska Pasaribu

: 2015

: PKH Beneficiary Families

: Nurliana Hutagaol

: 2015

: PKH Beneficiary Families

The data collection method was carried out by in-depth interviews (deep interviews) with open answers and a question structure that had been provided by the interviewer (attached) and field observations during the implementation of P2K2 activities in Balige District.

\section{E. RESEARCH RESULTS}

In this mini research, based on the results of interviews and observations made to social assistants and beneficiary families, several general findings were found which the authors will describe in the following table:

\begin{tabular}{|l|l|l|}
\hline No & Number of Beneficiary Families & Number of Officers \\
\hline & 540 Family Heads & 3 \\
\hline
\end{tabular}

The number of beneficiaries is 540 as shown in the table above. The number of components in each beneficiary family. These components will be the initial data and reference for the payment of PKH social assistance for families in accordance with the instructions for implementing existing activities. The components in the Balige sub-district are as follows.

\begin{tabular}{|r|l|l|}
\hline No & Component & Amount \\
\hline 1 & Pregnant mother & 8 \\
\hline 2 & Early childhood & 180 \\
\hline 3 & Elementary School student & 605 \\
\hline 4 & Junior High School student & 415 \\
\hline 5 & Senior High School student & 437 \\
\hline 6 & Elderly & 18 \\
\hline 7 & Disability & 3 \\
\hline & Total & 1.666 \\
\hline
\end{tabular}

Basically, the administrators of the Beneficiaries of the Family Hope Program are housewives, but due to several things, such as a wife who dies and is cheerful, sometimes the management is replaced by her husband and is obliged to attend monthly family capacity building meetings. Hereby the following table

\begin{tabular}{|l|l|l|}
\hline No & Gender & Amount \\
\hline & Man & 16 \\
\hline & Woman & 524 \\
\hline & Total & 540 Family \\
\hline
\end{tabular}

For types of work, the sources of income for beneficiary families are as follows:

\begin{tabular}{|l|l|l|}
\hline No & Type of work & Amount \\
\hline & Farmer & 497 \\
\hline
\end{tabular}


Volumes 1 No 1 (2021)

Communication Patterns Of Social Assistant Program For The Harapan Family In The Activities Of Family Capability Improvement Meetings (P2K2) Beneficiary Family (KPM) Balige District

Rammen Andino Sinaga

\begin{tabular}{|l|l|l|}
\hline 2 & Fisherman & 12 \\
\hline 3 & Trader & 21 \\
\hline 4 & Becak/Angkot Driver & 10 \\
\hline & Total & 540 \\
\hline
\end{tabular}

For the education level of the recipients of the Social Assistance Program for the Family Hope Program in Balige District, the following are the levels of education:

\begin{tabular}{|l|l|c|}
\hline No & \multicolumn{1}{|c|}{ Educational level } & Amount \\
\hline & Not completed in primary school & 42 \\
\hline & Elementary school graduate & 32 \\
\hline & Didn't finish high school & 44 \\
\hline & Middle school graduate & 110 \\
\hline & Didn't finish high school & 58 \\
\hline & finished high school & 254 \\
\hline & Total & 540 \\
\hline
\end{tabular}
follows:

The age range of the beneficiaries of the Family Hope Program social assistance is as

\begin{tabular}{|l|l|l|}
\hline No & Age Range & Amount \\
\hline & $20-30$ & 15 \\
\hline & $31-40$ & 220 \\
\hline & $41-50$ & 216 \\
\hline & $51-60$ & 57 \\
\hline & $61-70$ & 14 \\
\hline & 70 Years and Over & 18 \\
\hline & Total & 540 \\
\hline
\end{tabular}

From the tables above, researchers can take specific findings that can describe the condition of the Family Management Beneficiary of the Family Hope Program and how these special findings become obstacles in the communication pattern of social assistants, namely:

- The education level of the beneficiary administrators is junior high and high school so it is necessary to approach effective communication, not using communication language that is difficult for beneficiaries to understand.

- In terms of the age of the beneficiaries, the average age of the beneficiaries is productive, so it is necessary to use a communication approach to increase internal motivation in listening to family capacity building meetings.

- In terms of work, the average person is a farmer, so that in carrying out group meetings activities are carried out in the afternoon or on weekends so as not to interfere with concentration when conducting group meeting activities which sometimes hinder existing communication patterns.

- In terms of gender, social assistants must use language that is easily understood by women or mothers and pay attention to women's sensitivity in the use of semantic words. Because basically women are much more sensitive in hearing words.

The above are general findings in this mini research, which will be developed into specific findings in the study.

\section{Special Finding}




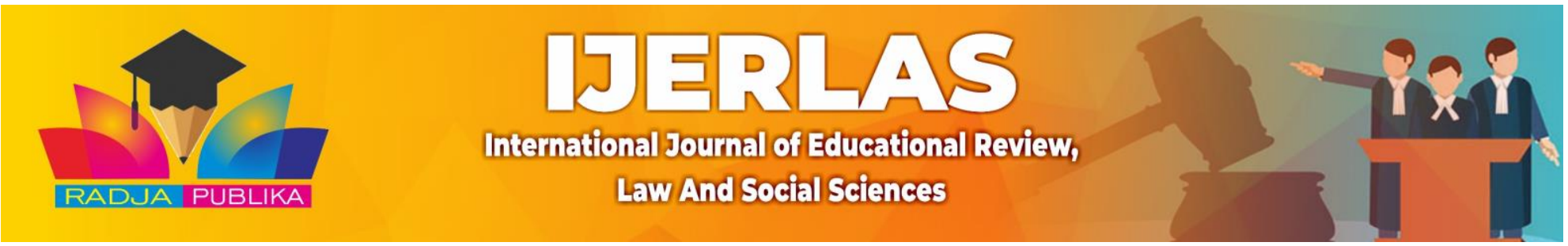

In the discussion of this particular finding, the researcher will divide in two ways the specific findings from the side of social assistants and special findings from the beneficiary side. Specific findings from the companion side will be juxtaposed with the theories of social barriers as listed above, this is to see the extent of the obstacles that occur in communication that occur in the implementation of the Family Capacity Building Meeting. A specific finding from the side of the beneficiaries of the social assistance is to see whether the communication carried out by the social facilitator has been effective or successful. The pattern of communication, has it had an impact in their daily activities and is juxtaposed with the theory of effective communication.

Specific findings from the point of view of the companion theory used is the theory of Communication Barriers by Onong Uchjana Effendy, in the book Science Theory and Philosophy of Communication, and the researcher will describe in the form of the table below:

\begin{tabular}{|c|c|c|c|}
\hline No & Resistance & $\begin{array}{l}\text { Obstacles That Occur in the P2K2 } \\
\text { Group }\end{array}$ & Barrier Repair Pattern \\
\hline & Disturbance & $\begin{array}{l}\text { The disturbance that occurs } \\
\text { mechanically is a disturbance } \\
\text { when KPM watches learning } \\
\text { videos, sometimes there are } \\
\text { villages that do not have an } \\
\text { existing focus shooting screen, for } \\
\text { speakers and mics they are not } \\
\text { used because the social assistant } \\
\text { uses the original voice. language } \\
\text { that is easy to understand and } \\
\text { combines the use of the Batak } \\
\text { language. The remaining obstacles } \\
\text { are illiterate KPMs, who cannot } \\
\text { read flipchart communication } \\
\text { media and the ability of } \\
\text { beneficiaries to express opinions } \\
\text { on the materials. }\end{array}$ & $\begin{array}{l}\text { For mechanical disturbances, the } \\
\text { infocus of social assistants will } \\
\text { maximize the use of speakers with a } \\
\text { rather strong volume, so that the } \\
\text { existing beneficiary KPM sitting in } \\
\text { the back can hear the explanation of } \\
\text { the video being played. For Semantic } \\
\text { Disorder for KPM who are illiterate, } \\
\text { the social assistant directs KPM who } \\
\text { can read Flipchart and instructs KPM } \\
\text { who can't read to repeat what his } \\
\text { friend said. To improve the ability and } \\
\text { motivation to express opinions. Social } \\
\text { assistants provide rewards with ice } \\
\text { breaking patterns such as applause } \\
\text { and other compliments }\end{array}$ \\
\hline & $\begin{array}{l}\text { Interest } \\
\text { interests }\end{array}$ & $\begin{array}{l}\text { Sometimes in the delivery of } \\
\text { teaching materials in group } \\
\text { meetings there are materials that } \\
\text { are of interest to the beneficiaries, } \\
\text { for example, an elderly person } \\
\text { does not feel interested in } \\
\text { discussing children's education, } \\
\text { because he does not have children } \\
\text { and feels that he is able to educate } \\
\text { children better than the material } \\
\text { presented and vice versa. young } \\
\text { mothers do not feel interested in } \\
\text { discussing the learning module for } \\
\text { elderly and disability }\end{array}$ & $\begin{array}{l}\text { The social assistant does a mapping of } \\
\text { what material will be discussed in the } \\
\text { group. If there are many parents in the } \\
\text { group, who have early childhood and } \\
\text { school children, the social assistant } \\
\text { decides to use Child Education and } \\
\text { Nutritional Health materials, the } \\
\text { opposite applies. If in a balanced } \\
\text { condition the components in the group } \\
\text { then the social assistant emphasizes } \\
\text { the function of the material, for } \\
\text { example if the elderly feel bored, the } \\
\text { social assistant conveys that this } \\
\text { material can be told to grandchildren } \\
\text { and daughter-in-law later. Social } \\
\text { assistants come not to teach but to } \\
\text { become facilitators and mentors. } \\
\text { Social assistants make Beneficiary } \\
\text { Families a source of learning. }\end{array}$ \\
\hline & Motivation & Intrinsic motivation that exists & The Social Facilitator before carrying \\
\hline
\end{tabular}


Communication Patterns Of Social Assistant Program For The Harapan Family In The Activities Of Family Capability Improvement Meetings (P2K2) Beneficiary Family (KPM) Balige District

Rammen Andino Sinaga

\begin{tabular}{|c|c|c|}
\hline & $\begin{array}{l}\text { within the beneficiary's family } \\
\text { may occur because of family } \\
\text { problems that cannot be solved by } \\
\text { the family. Intrinsic motivation } \\
\text { must be strengthened by the } \\
\text { presence of parties who provide } \\
\text { encouragement to KPM to provide } \\
\text { support and resilience capabilities } \\
\text { of the KPM. }\end{array}$ & $\begin{array}{l}\text { out P2K2 activities must confirm with } \\
\text { himself before coming in groups and } \\
\text { conducting Group Meetings. Mimics } \\
\text { and Gestures from enthusiastic social } \\
\text { assistants will provide strong } \\
\text { encouragement and motivation to the } \\
\text { beneficiaries. KPM fatigue from } \\
\text { every routine, needs to be anticipated } \\
\text { by social assistants before starting the } \\
\text { activity with ice breaking and singing } \\
\text { activities so that the learning process } \\
\text { is more comfortable and the material } \\
\text { conveyed through communication can } \\
\text { be absorbed by KPM social assistance } \\
\text { PKH }\end{array}$ \\
\hline $\begin{array}{l}\text { Predicte or } \\
\text { prejudice }\end{array}$ & $\begin{array}{l}\text { P2K2 activities are carried out in } \\
\text { the afternoon or on weekends. So } \\
\text { the social assistant must have more } \\
\text { time }\end{array}$ & $\begin{array}{l}\text { In the P2K2 group meeting, the social } \\
\text { assistant must look at the working } \\
\text { conditions of the assisted KPM so that } \\
\text { the KPM does not have bad } \\
\text { prejudices in the group meeting } \\
\text { process or think about their work. } \\
\text { KPM's calmness when receiving } \\
\text { messages from their social } \\
\text { companion's communication pattern is } \\
\text { the main thing in implementing } \\
\text { effective communication. }\end{array}$ \\
\hline
\end{tabular}

Specific findings from the point of view of the beneficiary families of the program The theory used is the theory of Effective communication by According to Mc. Crosky Larson and Knapp, in the book Introduction to Mass Communication Media Literacy and Culture, Edition, and will be described by the researcher in the form of the table below:

\begin{tabular}{|l|l|l|}
\hline No & \multicolumn{1}{|c|}{ Indicator } & \multicolumn{1}{c|}{ Explanation } \\
\hline Messages can be received and & $\begin{array}{l}\text { The message from the communication that has been } \\
\text { brought by the social assistant can be said to be accepted } \\
\text { and understood. At the end of the lesson, the KPM is } \\
\text { given a short quiz on the material presented. Such as the } \\
\text { ability to distinguish needs and desires when material is } \\
\text { Financial Management. }\end{array}$ \\
\hline Message can be understood & $\begin{array}{l}\text { The message from the communication that has been } \\
\text { delivered by the social facilitator can be said to be } \\
\text { understood when the beneficiary family provides } \\
\text { positive feedback or correct answers to questions raised } \\
\text { by the social assistant. If the existing feedback is not in } \\
\text { line with expectations, the social assistant will repeat the } \\
\text { correct statement and emphasize the statement. }\end{array}$ \\
\hline Message approved followed up & $\begin{array}{l}\text { The message from the communication that has been } \\
\text { brought by the social assistant can be said. The message } \\
\text { is approved and followed up is that KPM carries out } \\
\text { additional tasks from the submitted material, such as: In } \\
\text { terms of child care, the Social Assistance will check the }\end{array}$ \\
\hline
\end{tabular}




\begin{tabular}{|l|l|}
\hline $\mid \begin{array}{l}\text { child's school from the KPM, whether the child uses } \\
\text { school equipment that is complete, clean and tidy } \\
\text { because the learning objectives of the module are the } \\
\text { neatness and completeness of the child attending school. } \\
\text { On economics, social assistants will invite KPM to save } \\
\text { in a piggy bank, and at the end of the year the piggy } \\
\text { bank will be opened at a group meeting. This causes the } \\
\text { message to be followed up. }\end{array}$ \\
\hline
\end{tabular}

\section{F. CLOSING}

From the discussion above, the following conclusions can be drawn:

1. The communication used in Family Capacity Building activities is the type of interpersonal communication and group communication.

2. In P2K2 activities, social assistants must take an emotional approach to KPM $\mathrm{PKH}$ because with emotional closeness, it will increase the extrinsic motivation of KPM PKH.

3. Communication barriers in $\mathrm{P} 2 \mathrm{~K} 2$ activities, social assistants must take more persuasive and humane actions, so that the message conveyed can be well received.

4. P2K2 Balige District can be said to be effective communication, because the purpose, understanding and application of communication activities can be carried out properly.

\section{REFERENCES}

Alo Liliweri, Fundamentals of Intercultural Communication, Cet. IV Yogyakarta: Student Library, 2009

Dani Vardiansyah, Philosophy of Communication Science An Introduction, Cet. II Jakarta: PT Index, 2008 eJournal of Communication Studies, 2015, by Tita Novitasari "The Effectiveness of Parent and Child Interpersonal Communication in Instilling Knowledge of Regional Languages (Study on Javanese people in the village of Java Samarinda)

Eko Harry Susanto, Human Communication, Essence and Applications in Socio-Economic Political Dynamics, Edition. I, Jakarta: Media Discourse Partners, 2010

Ministry of Social Affairs RI. (2019). Family Capacity Building Meeting Module for the Hopeful Family Program

Khomsahrial Romli, Complete Organizational Communication, Cet. I, Edition. I Jakarta Grasindo, 2011

Kuntjorowati, Elly. (2018). The Influence of Empowerment of Beneficiary Families of the Hopeful Family Program through Family Development Sessions. Journal of Social Welfare Research. Vol. 17. No. 2. 2018

Muhammad Budyatna and Leila Mona Ganiem, Theory of Interpersonal Communication, Cet. I, Edition. I, Jakarta: Kencana, 2011)

Muhammad Budyatna and Leila Mona Ganiem, Theory of Interpersonal Communication, Cet. I, Edition. I, Jakarta: Kencana, 2011

Nasution, Zulkarimen. (2009). Communication development. Jakarta: Rajawali Press Onong Uchjana Effendy, Communication Theory and Philosophy, Cet. III, Bandung: PT. Samovar, Larry., Richard, E. Porter., dan

McDaniel, R. Edwin. (2014). Cross-Cultural Communication. Translation by Indri Margaretha Sidabalok. Jakarta: Salemba Humanika

Stanley J. Baran, Introduction to Mass Communication Media Literacy and Culture, Edition. New York: McGraw-Hill, 2009 